\title{
Exhaled Nitric Oxide and Airway Hyperresponsiveness to Adenosine 5'-monophosphate and Methacholine in Children with Asthma
}

\author{
Matthew S. Perzanowski ${ }^{a}$ Young Yoo ${ }^{\text {b-d }}$ \\ ${ }^{a}$ Department of Environmental Health Sciences, Mailman School of Public Health, Columbia University, \\ New York, N.Y., USA; ${ }^{b}$ Department of Pediatrics, College of Medicine and ${ }^{\mathrm{C}}$ Allergy Immunology Center, \\ Korea University, and ${ }^{\mathrm{d}}$ Environmental Health Center, Korea University Anam Hospital, Seoul, Korea
}

\section{Key Words}

Adenosine $5^{\prime}$-monophosphate · Airway

hyperresponsiveness . Childhood asthma.

Exhaled nitric oxide $\cdot$ Methacholine

\begin{abstract}
Background: There is increasing interest in the role of indirect bronchial challenges because clinical studies have shown that indirect airway hyperresponsiveness (AHR) reflects underlying airway inflammation better than direct AHR. Fractional exhaled nitric oxide (FeNO) appears to be a useful clinical tool for assessing airway inflammation noninvasively. We examined whether FeNO is more closely related to AHR to indirect stimuli than AHR to direct stimuli in children with mild to moderate asthma. Methods: Fifty-nine asthmatic children aged 6-16 years without rhinitis, underwent spirometry, FeNO measurement and blood tests for serum total IgE, blood eosinophil count and serum eosinophil cationic protein (ECP). All subjects underwent methacholine and adenosine 5-monophosphate (AMP) challenge tests at intervals of 3 days. Results: In a univariate linear regression analysis, FeNO was significantly associated with both $\mathrm{PC}_{20}$ AMP $\left(R^{2}=0.341, \mathrm{p}<0.001\right)$ and $\mathrm{PC}_{20}$ methacholine $\left(R^{2}=\right.$ $0.188, p=0.001$ ). After adjustment for age, sex, serum total $\lg \mathrm{E}$ and blood eosinophil count, the association between FeNO and $\mathrm{PC}_{20} \mathrm{AMP}(\beta=-1.98, p=0.001)$ was more robust
\end{abstract}

than that between FeNO and $\mathrm{PC}_{20}$ methacholine $(\beta=-0.87$, $p=0.081)$. The significant correlation between FeNO and $P C_{20}$ AMP was observed in the steroid-naïve group $(\beta=$ $-2.48, p=0.001$ ), but not in the steroid-treated group $(\beta=$ $0.88, p=0.463)$. Conclusions: FeNO levels were more closely associated with $\mathrm{PC}_{20}$ AMP than with $\mathrm{PC}_{20}$ methacholine. This relationship could only be seen in the steroid-naiive subjects. These results suggest that FeNO levels in children with asthma may be more closely related to indirect AHR than to direct AHR.

(c) 2015 S. Karger AG, Basel

\section{Introduction}

Asthma is one of the most common chronic diseases in children. Airway hyperresponsiveness (AHR) and airway inflammation are two main characteristics of asthma [1]. It has been shown that airway inflammation contributes to AHR, even though the presence and severity of AHR are related to smooth muscle contraction.

AHR is defined as an exaggerated bronchoconstrictive response of the airway to a variety of stimuli and can be measured by using direct or indirect stimuli. Direct stimuli, such as with methacholine, induce airway narrowing mainly through direct action on the receptors of airway smooth muscles [2], whereas indirect stimuli, such as

\section{KARGER 125}

(c) 2015 S. Karger AG, Base

$1018-2438 / 15 / 1662-0107 \$ 39.50 / 0$ 
with adenosine $5^{\prime}$-monophosphate (AMP), cause airway narrowing mainly via the stimulation of primed mast-cell degranulation and the release of proinflammatory mediators [3]. Thus, airway inflammation also appears to be a major factor determining the degree of AHR and airflow obstruction.

Exhaled nitric oxide (eNO) is a noninvasive marker of airway inflammation. In recent years, fractional eNO (FeNO) has become a valuable tool for the diagnosis and monitoring of asthma in childhood [4]. Previous studies investigating relationships between FeNO and AHR have shown inconsistent results and the correlations were generally low [5-7]. Some studies concerning atopic steroidnaïve asthmatics have demonstrated significant associations between FeNO and AHR [5]; others performed on steroid-treated asthmatics have not $[7,8]$. FeNO measurement is increasingly useful for the diagnosis and management of asthma. However, the clinical validity of FeNO in asthmatics is not well established or widely accepted because of the significant phenotypic heterogeneity of asthma. Moreover, FeNO levels are elevated not only in patients with asthma but also in patients with rhinitis and other upper airway diseases as well as in atopic subjects without respiratory disease [9].

Although FeNO and AHR most likely represent different aspects of inflammation and structural changes in the airways, a further understanding of the relationships between clinical markers of airway inflammation, airflow obstruction and airway hyperreactivity in asthmatics may have clinical implications. Since AHR to indirect stimuli reflect allergic airway inflammation better than AHR to direct stimuli [10], we hypothesized that FeNO would be more closely related to indirect bronchial challenge than to direct bronchial challenge. We thus examined whether FeNO would be more closely associated with AHR to AMP than with AHR to methacholine.

\section{Materials and Methods}

\section{Study Population}

This study was performed on 59 children aged 6-16 years with mild to moderate, persistent asthma who were recruited from the Allergy Clinic of the Korea University Anam Hospital, Seoul, Korea. Inclusion criteria were physician-diagnosed asthma and a history of episodic wheezing and/or dyspnea during the past year that was resolved with a bronchodilator. Subjects with a history of near-fatal asthma, major exacerbations necessitating the use of systemic corticosteroids or other respiratory diseases were excluded from the study. Seventeen subjects were taking asthma medicine regularly prior to testing. Eleven subjects were using inhaled corticosteroids (ICSs), 5 were taking leukotriene modi- fiers and 1 was taking oral theophylline as a controller medicine. They were divided into a steroid-treated group $(n=11)$ and a steroid-naïve group $(n=48)$. Subjects with any history of symptoms suggestive of current allergic rhinitis, such as recurrent sneezing, rhinorrhea and nasal stuffiness or itching in the absence of a common cold within the past 12 months were also excluded. The clinical severity of asthma was assessed according to the $\mathrm{Na}$ tional Asthma Education and Prevention Program criteria [11].

Parents gave written informed consent for their children to participate in the study. The study protocol was approved by the Korea University Anam Hospital Institutional Review Board (No. AN09226-003).

\section{Pulmonary Function Tests}

Forced expiratory volume in $1 \mathrm{~s}\left(\mathrm{FEV}_{1}\right)$ and forced vital capacity (FVC) were measured using a computerized spirometer (Microspiro-HI 298, Chest, Tokyo, Japan), in accordance with the recommendations of the American Thoracic Society [12]. All subjects were asked to undergo spirometry in a reproducible way (i.e. a coefficient of variation of $\mathrm{FEV}_{1}$ in 3 consecutive flow-volume curves of $<5 \%$ ) and to achieve an $\mathrm{FEV}_{1}$ of at least $60 \%$ of the predicted value. The largest value of triplicate $\mathrm{FEV}_{1}$ on each occasion was used for analysis.

\section{Methacholine and AMP Challenges}

Methacholine challenge tests were carried out using a modification of the method described by Chai et al. [13]. AMP challenge tests were carried out using a modification of the method of the European Respiratory Society [14]. Patients were asked to discontinue the use of inhaled $\beta 2$-agonists (for $24 \mathrm{~h}$ ), oral theophylline (for $48 \mathrm{~h}$ ), leukotriene modifiers and ICSs (for 7 days) at least before testing. Each patient had been free of acute respiratory tract infections for at least 4 weeks prior to the tests.

Fresh methacholine and AMP solutions were prepared in buffered saline solution at different concentrations $(0.075,0.15,0.3$, $0.625,1.25,2.5,5,10,25$ and $50 \mathrm{mg} / \mathrm{ml}$ for methacholine; 3.125 , $6.25,12.5,25,50,100,200$ and $400 \mathrm{mg} / \mathrm{ml}$ for AMP). A RosenthalFrench dosimeter (Laboratory for Applied Immunology, Baltimore, Md., USA), triggered by a solenoid valve set to remain open for $0.6 \mathrm{~s}$, was used to generate an aerosol from a DeVilbiss 646 nebulizer (DeVilbiss Health Care, Somerset, Pa., USA) with pressurized air at 20 psi. Each subject inhaled 5 inspiratory capacity breaths of a buffered saline solution and increasing concentrations of methacholine or AMP, respectively, at 5-min intervals. This setup produced an output of $0.009 \pm 0.0014 \mathrm{ml}$ (mean \pm SD) per inhalation. At each concentration, $\mathrm{FEV}_{1}$ was measured $90 \mathrm{~s}$ after inhalation. The procedure was terminated when $\mathrm{FEV}_{1}$ decreased by $>20 \%$ of its post-saline value or when the highest methacholine $(50 \mathrm{mg} / \mathrm{ml})$ or AMP $(400 \mathrm{mg} / \mathrm{ml})$ concentration was reached.

Percentage declines in $\mathrm{FEV}_{1}$ from the post-saline value were plotted against the log concentrations of inhaled methacholine or AMP. $\mathrm{PC}_{20}$ methacholine and $\mathrm{PC}_{20}$ AMP were calculated by interpolating between 2 adjacent data points whenever $\mathrm{FEV}_{1}$ decreased by $>20 \%$. For statistical analyses, a censored value of $800 \mathrm{mg} / \mathrm{ml}$ for $\mathrm{PC}_{20}$ AMP was assigned to subjects who did not show a $20 \%$ decline in $\mathrm{FEV}_{1}$ after inhalation of the maximal concentration of AMP. A cumulative provocative dose causing a $20 \%$ fall in $\mathrm{FEV}_{1}$ $\left(\mathrm{PD}_{20} \mathrm{AMP}\right)$ was calculated by log-linear interpolation of the final data points. The dose-response ratio (DRR) was calculated by obtaining the final percentage fall in $\mathrm{FEV}_{1}$ and dividing it by the cumulative dose of AMP administered. 
Table 1. Clinical characteristics of the 2 study groups

\begin{tabular}{lccc}
\hline Parameters & Steroid-treated $(\mathrm{n}=11)$ & Steroid-naïve $(\mathrm{n}=48)$ & Total $(\mathrm{n}=59)$ \\
\hline Age, years & $10.0 \pm 2.7$ & $9.9 \pm 2.7$ & $9.9 \pm 2.7$ \\
Boys, \% & 72.7 & 66.7 & 67.8 \\
Positive skin-prick test, $\%$ & 90.9 & 70.8 & 74.6 \\
Total IgE, IU/ml $^{\mathrm{a}}$ & $249.6(5.5-837.1)$ & $144.0(28.8-720.5)$ & $158.5(33.9-741.3)$ \\
${\text { Blood eosinophil count, } / \mu l^{\mathrm{a}}}_{\text {FeNO, }^{\mathrm{a}} \mathrm{pb}^{\mathrm{a}} \mathrm{b}}$ & $267.7(85.6-837.1)$ & $278.7(126.5-614.0)$ & $275.4(117.5-645.7)$ \\
& $54.1(31.2-93.7)$ & $30.0(18.2-49.4)$ & $33.3(19.0-57.9)$ \\
\hline
\end{tabular}

${ }^{\text {a }}$ Geometric mean (range of $1 \mathrm{SD}$ ).

${ }^{\mathrm{b}} \mathrm{p}<0.05$.

\section{Measurement of FeNO}

Exhaled NO was measured according to American Thoracic Society recommendations using an NO analyzer (NIOX MINO analyzer, Aerocrine, Solna, Sweden) during single-breath exhalation [15]. Subjects inhaled NO-free air to total lung capacity and immediately exhaled fully against a positive mouthpiece counter to pressure at a flow rate of $50 \mathrm{ml} / \mathrm{s}$ into an on-line analyzer to avoid any nasal contamination.

\section{Skin-Prick Tests}

Skin-prick tests were performed using 13 common aeroallergens: house dust mites (Dermatophagoides pteronyssinus and Dermatophagoides farinae), animal danders (cat epithelium and dog epithelium), pollens (mugwort, ryegrass, ragweed, hazel, alder and oak), molds (Aspergillus fumigates and Alternaria alternata) and cockroach (Blatella germanica). The allergens were supplied by Allergopharma (Reinbek, Germany). A mean wheal diameter $>3 \mathrm{~mm}$ in the absence of any reaction to the negative control was considered a positive reaction. Atopy was defined as the presence of at least 1 positive reaction to these allergens greater than the negative control.

\section{Serum total IgE and Blood Eosinophil Markers}

Serum total IgE levels were measured using a Coat-A-Count Total IgE IRMA (Diagnostic Products Co., Los Angeles, Calif., USA) according to the manufacturer's instructions. The number of peripheral blood eosinophils was counted with blood samples containing EDTA using an automated hematology analyzer (Coulter Counter STKS, Beckman Coulter, Fullerton, Calif., USA). Serum ECP levels were measured using a commercially available fluoroimmunoassay kit (Pharmacia ECP UniCAP System FEIA, Pharmacia Diagnostics, Uppsala, Sweden) which had a detection limit of $<2.0 \mu \mathrm{g} / \mathrm{l}$. Blood sample collection, serum preparation and serum ECP measurement were performed according to the manufacturer's instructions.

\section{Statistical Analysis}

A sample size of 61 was achieved by $80 \%$ power to detect a difference of -0.35 between the null hypothesis correlation of 0.00 and the alternative hypothesis correlation of 0.35 , using a 2 -sided hypothesis test with a significance level of 0.05 with PASS 12 (NCSS, LLC, Kaysville, Utah, USA). Data are presented as mean \pm $\mathrm{SD}$. The values for FeNO, $\mathrm{PC}_{20}$ methacholine, $\mathrm{PC}_{20} \mathrm{AMP}, \mathrm{PD}_{20}$
AMP, DRR, serum total IgE, serum ECP and blood eosinophil counts were log transformed before statistical analysis. The maximal percentage fall in $\mathrm{FEV}_{1}$ from baseline after administration of AMP was calculated. The means or frequencies were compared between the 2 groups using the 2 -tailed Student $t$ test or the $\chi^{2}$ test. Relationships between FeNO and serum IgE level/eosinophil count/ECP level were measured using the Pearson correlation coefficients. Multivariable linear regression models were used to analyze the association between $\mathrm{FeNO}$ and $\mathrm{PC}_{20}$ methacholine $/ \mathrm{PC}_{20}$ AMP, after adjustment for age, sex, serum total IgE level and blood eosinophil count. The coefficient of determination $\left(R^{2}\right)$ and regression coefficient $(\beta)$ were obtained from the analyses. All statistical analyses were performed using SPSS software (version 17; SPSS Inc., Chicago, Ill., USA). A p value of $<0.05$ was considered statistically significant.

\section{Results}

The clinical characteristics of the steroid-treated and steroid-naïve groups of children with mild to moderate, persistent asthma are shown in table 1 . There was no significant difference in age, sex ratio and blood eosinophil count between the 2 groups. The geometric mean of serum total IgE levels of the steroid-treated group [249.6 $\mathrm{IU} / \mathrm{ml}$ (5.5-837.1)] was not significantly different from those of the steroid-naïve group [144.0 IU/ml $(28.8-$ 720.5), $\mathrm{p}=0.290$ ]. However, the prevalence of atopy showed a marginal significance between the 2 groups ( 90.9 vs. $70.8 \%, \mathrm{p}=0.050$ ). The geometric mean of FeNO levels was significantly higher in the steroid-treated group than in the steroid-naïve group [54.1 ppb (31.2-93.7) vs. $30.0 \mathrm{ppb}(18.2-49.4), \mathrm{p}=0.006]$.

The pulmonary function parameters of the 2 groups are presented in table 2 . There was no significant difference in baseline pulmonary function parameters and $\mathrm{PC}_{20}$ methacholine between the 2 groups. The geometric mean (range of $1 \mathrm{SD}$ ) of $\mathrm{PC}_{20} \mathrm{AMP}$ was significantly lower in the 
Table 2. Pulmonary function parameters and AHR in steroid-treated and steroid-naïve asthmatic children

\begin{tabular}{|c|c|c|c|}
\hline $\mathrm{FEV}_{1}, \%$ predicted & $96.5 \pm 15.8$ & $96.3 \pm 14.9$ & $96.4 \pm 14.9$ \\
\hline FVC, \% predicted & $96.1 \pm 12.8$ & $98.9 \pm 11.7$ & $98.4 \pm 11.9$ \\
\hline $\mathrm{FEV}_{1} / \mathrm{FVC}, \%$ & $85.0 \pm 7.0$ & $83.1 \pm 7.8$ & $83.5 \pm 7.6$ \\
\hline $\mathrm{PC}_{20}$ methacholine, $\mathrm{mg} / \mathrm{ml}^{\mathrm{a}}$ & $2.01(0.23-17.7)$ & $4.31(0.72-25.9)$ & $3.4(0.6-21.0)$ \\
\hline $\mathrm{PC}_{20} \mathrm{AMP}, \mathrm{mg} / \mathrm{ml}^{\mathrm{a}, \mathrm{b}}$ & $18.5(3.06-112.2)$ & $89.1(8.5-934.5)$ & $66.4(6.5-677.6)$ \\
\hline $\mathrm{PD}_{20} \mathrm{AMP}, \mathrm{mg}^{\mathrm{a}}$ & $18.7(3.13-111.2)$ & $63.9(8.36 \pm 489.3)$ & $50.9(6.7-389.2)$ \\
\hline $\mathrm{DRR}, \%$ fall $/ \mathrm{mg}^{\mathrm{a}, \mathrm{b}}$ & $1.56(0.23-10.5)$ & $0.30(0.25-3.67)$ & $0.41(0.03-4.85)$ \\
\hline
\end{tabular}

${ }^{a}$ Geometric mean (range of $\left.1 \mathrm{SD}\right)$.

${ }^{\mathrm{b}} \mathrm{p}<0.05$.

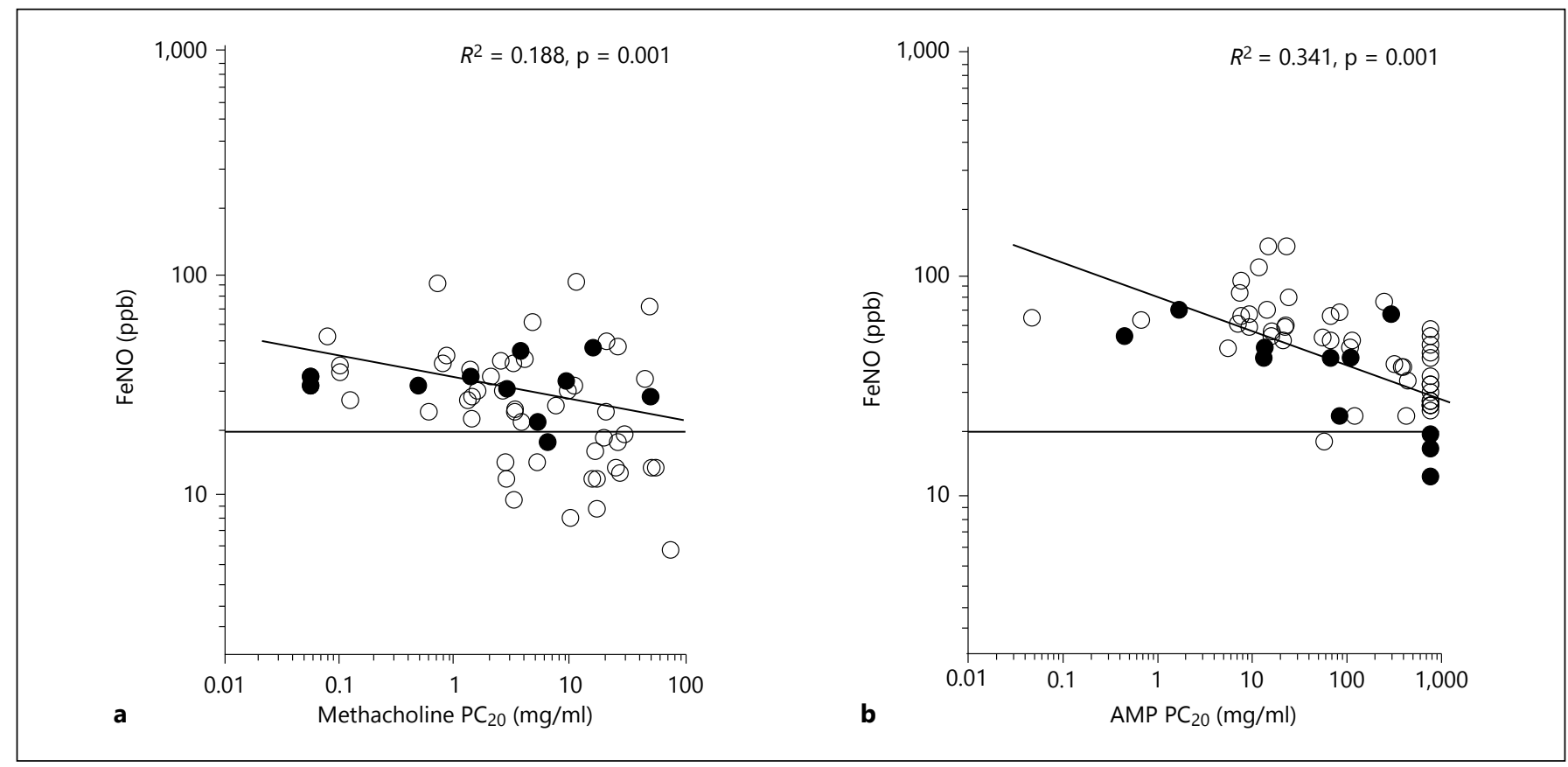

Fig. 1. a Association between FeNO and $\mathrm{PC}_{20}$ methacholine. b Association between $\mathrm{FeNO}$ and $\mathrm{PC}_{20} \mathrm{AMP}$. Open circles indicate steroid-naïve asthmatics and closed circles indicate steroid-treated asthmatics.

steroid-treated group than in the steroid-naïve group [18.5 $\mathrm{mg} / \mathrm{ml}$ (3.06-112.2) vs. $89.1 \mathrm{mg} / \mathrm{ml}$ (8.5-934.5), $\mathrm{p}=$ 0.042 ]. The mean percent fall in $\mathrm{FEV}_{1}$ was not significantly different between the steroid-treated group and the steroid-naïve group ( $25.5 \pm 9.4$ vs. $23.7 \pm 11.8 \%)$. There were 17 subjects who did not show a positive response after inhalation of the maximal concentration of AMP (400 $\mathrm{mg} / \mathrm{ml})$. The DRR was significantly higher in the steroidtreated group than in the steroid-naïve group [1.56\% fall/ $\mathrm{mg}(0.23-10.5)$ vs. $0.30 \%$ fall $/ \mathrm{mg}(0.25-3.67), \mathrm{p}=0.046]$.
In the univariate analysis, FeNO was significantly associated with both $\mathrm{PC}_{20} \mathrm{AMP}\left(R^{2}=0.341, \mathrm{p}<0.001\right)$ and $\mathrm{PC}_{20}$ methacholine $\left(R^{2}=0.188, \mathrm{p}=0.001\right.$; fig. 1$)$. However, in the multivariable linear regression model, after controlling for age, sex, serum total IgE and blood eosinophil count, FeNO was independently associated with $\mathrm{PC}_{20}$ AMP $(\beta=-1.98, \mathrm{p}=0.001)$, but not with $\mathrm{PC}_{20}$ methacholine $(\beta=-0.87, p=0.081$; table 3$)$. A significant association between $\mathrm{FeNO}$ and $\mathrm{PC}_{20} \mathrm{AMP}$ was found in the steroid-naïve group $(\beta=-2.48, p=0.001)$, but not in 
Table 3. Multivariable models for associations between FeNO and $\mathrm{PC}_{20}$ methacholine/PC ${ }_{20} \mathrm{AMP}$ in the study subjects

\begin{tabular}{|c|c|c|c|c|c|c|}
\hline & \multicolumn{3}{|c|}{$\mathrm{PC}_{20}$ methacholine } & \multicolumn{3}{|c|}{$\mathrm{PC}_{20} \mathrm{AMP}$} \\
\hline & $\beta$ & $95 \% \mathrm{CI}$ & $\mathrm{p}$ value & $\beta$ & $95 \% \mathrm{CI}$ & $\mathrm{p}$ value \\
\hline FeNO, ppb & -0.87 & -1.86 to 0.11 & 0.081 & -1.98 & -3.11 to -0.85 & 0.001 \\
\hline Age & 0.00 & -0.08 to 0.08 & 0.998 & -0.01 & -0.11 to 0.08 & 0.770 \\
\hline Sex & 0.14 & -0.32 to 0.60 & 0.543 & -0.21 & -0.74 to 0.32 & 0.427 \\
\hline Total IgE, IU/ml & -0.33 & -0.68 to 0.02 & 0.061 & -0.34 & -0.74 to 0.06 & 0.090 \\
\hline Eosinophils, / $\mu \mathrm{l}$ & -0.19 & -0.76 to 0.38 & 0.502 & -0.12 & -0.77 to 0.53 & 0.713 \\
\hline
\end{tabular}

Table 4. Multivariable models for associations between $\mathrm{FeNO}$ and $\mathrm{PC}_{20}$ methacholine/ $\mathrm{PC}_{20} \mathrm{AMP}$ in the steroid-treated group

\begin{tabular}{|c|c|c|c|c|c|c|}
\hline & \multicolumn{3}{|c|}{$\mathrm{PC}_{20}$ methacholine } & \multicolumn{3}{|c|}{$\mathrm{PC}_{20}$ AMP } \\
\hline & $\beta$ & $95 \% \mathrm{CI}$ & $\mathrm{p}$ value & $\beta$ & $95 \% \mathrm{CI}$ & $\mathrm{p}$ value \\
\hline FeNO, ppb & 1.01 & -3.74 to 5.76 & 0.607 & 0.88 & -1.96 to 3.72 & 0.463 \\
\hline Age & -0.14 & -0.91 to 0.63 & 0.650 & -0.78 & -0.54 to 0.38 & 0.682 \\
\hline Sex & -1.29 & -6.81 to 4.24 & 0.575 & 2.22 & -1.08 to 5.52 & 0.144 \\
\hline Total IgE, IU/ml & -0.20 & -2.11 to 1.71 & 0.796 & -1.12 & -2.26 to 0.02 & 0.053 \\
\hline Eosinophils, $/ \mu \mathrm{l}$ & -1.26 & -3.02 to 0.49 & 0.123 & 0.88 & -1.25 to 0.85 & 0.463 \\
\hline
\end{tabular}

Table 5. Multivariable models for associations between $\mathrm{FeNO}$ and $\mathrm{PC}_{20}$ methacholine/ $\mathrm{PC}_{20} \mathrm{AMP}$ in the steroid-naive group

\begin{tabular}{|c|c|c|c|c|c|c|}
\hline & \multicolumn{3}{|c|}{$\mathrm{PC}_{20}$ methacholine } & \multicolumn{3}{|c|}{$\mathrm{PC}_{20}$ AMP } \\
\hline Age & 0.08 & -0.12 to 2.73 & 0.428 & 0.05 & -0.19 to 0.30 & 0.669 \\
\hline Sex & 1.15 & 0.08 to 2.22 & 0.035 & 0.12 & -0.19 to 1.44 & 0.851 \\
\hline Total IgE, IU/ml & 0.55 & 0.19 to 0.91 & 0.004 & -0.14 & -0.58 to 0.31 & 0.538 \\
\hline
\end{tabular}

the steroid-treated group $(\beta=0.88, \mathrm{p}=0.463)$ (tables 4 , $5)$. There was a positive relationship of FeNO concentrations to blood eosinophil markers $(r=0.34, \mathrm{p}=0.009)$ and serum ECP levels $(r=0.29, \mathrm{p}=0.027)$. FeNO concentrations were also positively associated with serum total IgE concentrations $(r=0.47, \mathrm{p}=0.001)$, but not with $\mathrm{FEV}_{1} /$ $\operatorname{FVC}(r=-0.11, \mathrm{p}=0.402)$.

\section{Discussion}

In this study, we demonstrated that FeNO concentrations were more closely associated with AHR to AMP than with AHR to methacholine in asthmatic children. A significant association between FeNO and AHR to AMP was observed in the steroid-naïve group, but not in the steroid-treated group. FeNO was positively correlated with serum total IgE and blood eosinophil markers but not with baseline pulmonary function parameters.

Airway inflammation and AHR are two main characteristic features of asthma. AHR, an exaggerated response to stimuli, can be measured using direct (methacholine) and indirect (AMP) stimuli. There is increasing interest in indirect testing by releasing mediators because AHR is an indicator of the presence of airway inflammation [3]. AMP, unlike methacholine, does not act as a bronchoconstrictor agent by acting directly on airway smooth muscle, but acts rather via mediators re- 
leased from activated mast cells [10]. Inhaled AMP acts through $\mathrm{A} 2 \mathrm{~B}$ receptors and is thought to result in bronchoconstriction via mast-cell degranulation that releases histamine and other cytokines [16]. Inhaled AMP increased the eosinophil count in the lungs in a sensitized animal model [17]. Recruited eosinophils may reflect an overall increased inflammatory activity, increasing the production of cytokines that stimulate mast cells directly and indirectly. Activation of mast cells can also occur through the IgE-dependent pathway, resulting in the release of mediators that are responsible for an influx of eosinophils in the sputum [16]. Therefore, AHR to AMP reflects underlying airway inflammation more specifically [18].

A proportion of our subjects responded to methacholine, but not to AMP. AHR to direct stimuli may be present in the absence of AHR to indirect stimuli. This indicates that airway damage or airflow limitation without airway inflammation may occur in asthmatic airways [19]. Eleven subjects were taking ICSs prior to testing. In current asthma, airway inflammation is the central abnormality leading to AHR, and treating airway inflammation with ICSs may have greater effects on indirect challenges than on direct challenges $[8,20]$.

Meanwhile, airway inflammation can be noninvasively assessed with FeNO. NO is synthesized by various cells through the oxidation of L-arginine by NO synthase. In asthma, inducible NO synthase expression is upregulated by activating STAT- 6 through interleukins 4 and 13 produced by Thelper 2 cells, mast cells and eosinophils [4, 21 . Thus, eNO directly signals the proinflammatory cytokine mechanisms of central importance in the pathophysiology of asthma. The levels of eNO parallel the inflammatory process in the asthmatic airway, and treatment with ICSs results in a marked reduction in the levels of eNO [22]. On the other hand, the degree of IgE sensitization is also thought to be related to eNO, although eosinophilic inflammation is commonly considered an important contributor [21,23]. Atopic inflammation is characterized by the recruitment and activation of eosinophils; therefore, both atopy and eosinophils might be important determinants of NO production [21].

Relationships between FeNO and indirect AHR have been shown in numerous studies [24-26]. Both FeNO and indirect AHR are increased in asthma; however, not all asthma phenotypes are characterized by significant relationships between these 2 parameters. Previous studies have shown that FeNO is significantly associated with indirect AHR in atopic subjects, but not in nonatopic subjects $[24,25]$. This association is, in part, due to the dif- ferences in inflammatory profiles or cytokine production between atopic and nonatopic asthmatics. It is suggested that both FeNO levels and the response to AMP challenge depend on the degree of allergic airway inflammation in asthmatics [21, 24].

In this study, we demonstrated that FeNO was more closely associated with AHR to AMP than with AHR to methacholine. Consistent with these results, Porsbjerg et al. [5] showed that FeNO has a stronger correlation with indirect stimuli (mannitol) than with direct stimuli (methacholine). A previous study showed that an improvement in $\mathrm{PC}_{20} \mathrm{AMP}$ but not in $\mathrm{PC}_{20}$ methacholine after 2 weeks of steroid therapy is associated with a decrease in FeNO, indicating that AHR to AMP is more closely associated with airway inflammation [27].

When we conducted subanalyses on the steroid-treated and steroid-naïve groups, significant relationships were observed only in the steroid-naïve group. Other studies have shown no correlations between FeNO and indirect AHR in steroid-treated subjects, supporting the notion that the inflammatory response in the airways could be attenuated by ICSs [8].

Several points must be considered. Of the 59 subjects that we studied, 11 were taking ICSs prior to enrollment. Treating with ICSs may attenuate inflammation, may possibly inhibit airway sensitivity to indirect stimuli and, thus, impact relationships between the two. ICS washout for 1 week may not have been sufficient in our subjects. Another point to be considered is that we attempted to exclude current rhinitis patients going by their symptoms. The absence of rhinitis symptoms within the last 12 months does not always exclude the possibility of allergic rhinitis.

In summary, we found that airway inflammation, as assessed by using eNO, was more closely associated with AMP responsiveness than with methacholine responsiveness in steroid-naïve asthmatic children. Our results suggest that FeNO may better reflect bronchial responsiveness when assessed by indirect challenge than by direct challenge.

\section{Acknowledgements}

This study was supported by grants from the Environmental Health Center for Childhood Asthma, Ministry of Environment, Korea, the Korean Health Technology R\&D Project, Ministry of Health \& Welfare, Korea (A110663) and the Basic Science Research Program through the National Research Foundation of Korea, Ministry of Education, Science and Technology, Korea (2012R1A1A3014036). 


\section{References}

1 National Heart, Lung, and Blood Institute: Definition, pathophysiology and pathogenesis of asthma, and natural history of asthma; in: Expert Panel Report 3: Guidelines for the Diagnosis and Management of Asthma (NIH publication No. 08-4051). Bethesda, US Department of Health and Human Services, 2007.

2 Hargreave FE, Dolovich J, O'Byrne PM, Ramsdale EH, Daniel EE: The origin of airway hyperresponsiveness. J Allergy Clin Immunol 1986;78:825-832.

3 de Meer G, Marks GB, Postma DS: Direct or indirect stimuli for bronchial challenge testing: what is the relevance for asthma epidemiology? Clin Exp Allergy 2004;34:9-16.

4 Ludviksdottir D, Diamant Z, Alving K, Bjermer L, Malinovschi A: Clinical aspects of using exhaled $\mathrm{NO}$ in asthma diagnosis and management. Clin Respir J 2012;6:193-207.

5 Porsbjerg C, Brannan JD, Anderson SD, Backer V: Relationships between airway responsiveness to methacholine and markers of airway inflammation, peak flow variability and quality of life in asthma patients. Clin Exp Allergy 2007;38:43-50.

6 Berkman N, Avital A, Breuer R, Bardach E, Springer C, Godfrey S: Exhaled nitric oxide in the diagnosis of asthma: comparison with bronchial provocation tests. Thorax 2005;60: 383-388.

7 Van den Berge M, Meijer RJ, Kerstjens HA, de Reus DM, Koeter GH, Kauffman HF, Postma DS: $\mathrm{PC}_{20}$ adenosine 5 -monophosphate is more closely associated with airway inflammation in asthma than $\mathrm{PC}_{20}$ methacholine. Am J Respir Crit Care Med 2001;163:15461550.

8 Leuppi JD, Salome CM, Jenkins CR, Koskela $\mathrm{H}$, Brannan JD, Anderson SD, Andersson M, Chan HK, Woolcock AJ: Markers of airway inflammation and airway hyperresponsiveness in patients with well-controlled asthma. Eur Respir J 2001;18:444-450.

9 Linhares D, Jacinto T, Pereira AM, Fonseca JA: Effects of atopy and rhinitis on exhaled nitric oxide value - a systematic review. Clin Transl Allergy 2011;1:8.
10 Spicuzza L, Polosa R: The role of adenosine as a novel bronchoprovocant in asthma. Curr Opin Allergy Clin Immunol 2003;3:65-69.

11 National Asthma Education and Prevention Program: Expert Panel Report 2: Guidelines for the Diagnosis and Management of Asthma (NIH publication No. 97-4051). Bethesda, US Department of Health and Human Services, 1997.

12 American Thoracic Society: Standardization of spirometry, 1984 update. Am J Respir Crit Care Med 1995;152:1107-1136.

13 Chai H, Farr RS, Froehlich LA, Mathison DA, McLean JA, Rosenthal RR, Sheffer AL, Spector SL, Townley RG: Standardization of bronchial inhalation challenge procedures. J Allergy Clin Immunol 1975;56:323-327.

14 Joos GF, O'Connor B, Anderson SD, Chung F, Cockcroft DW, Dahlen B, DiMaria G, Foresi A, Hargreave FE, Holgate ST, Inman M, Lotvall J, Magnussen H, Polosa R, Postma DS, Riedler J; ERS Task Force: Indirect airway challenges. Eur Respir J 2003;21:1050-1068.

15 Dweik RA, Boggs PB, Erzurum SC, Irvin CG, Leigh MW, Lundberg JO, Olin AC, Plummer AL, Taylor DR: An official ATS clinical practice guideline: interpretation of exhaled nitric oxide levels (FENO) for clinical applications. Am J Respir Crit Care Med 2011;184:602615.

16 Vass G, Horvath I: Adenosine and adenosine receptors in the pathomechanism and treatment of respiratory diseases. Curr Med Chem 2008;15:917-922

17 Smith N, Johnson FJ: Early- and late-phase bronchoconstriction, airway hyper-reactivity and cell influx into the lungs, after 5 -adenosine monophosphate inhalation: comparison with ovalbumin. Clin Exp Allergy 2005;35: 522-530.

18 Anderson SD: Provocative challenges to help diagnose and monitor asthma: exercise, methacholine, adenosine, and mannitol. Curr Opin Pulm Med 2008;14:39-45.
19 Cockcroft DW: Direct challenge tests: airway hyperresponsiveness in asthma: its measurement and clinical significance. Chest 2010; 138:18S-24S

20 O'Connor BJ, Ridge SM, Barnes PJ, Fuller RW: Greater effect of inhaled budesonide on adenosine $5^{\prime}$-monophosphate-induced than on sodium-metabisulfite-induced bronchoconstriction in asthma. Am Rev Respir Dis 1992;146:560-564.

21 Alving K, Malinovschi A: Basic aspects of exhaled nitric oxide. Eur Respir Mon 2010;49: $1-31$.

22 van Rensen EL, Straathof KC, Veselic-Charvat MA, Zwinderman AH, Bel EH, Sterk PJ: Effect of inhaled steroids on airway hyperresponsiveness, sputum eosinophils, and exhaled nitric oxide levels in patients with asthma. Thorax 1999;54:403-408.

23 Jang WN, Park IS, Choi CH, Bauer S, Harmin S, Seo SC, Choi IS, Choung JT, Yoo Y: Relationships between exhaled nitric oxide and atopy profiles in children with asthma. Allergy Asthma Immunol Res 2013;5:155-161.

24 Rouhos A, Ekroos H, Karjalainen J, Sarna S, Sovijarvi AR: Exhaled nitric oxide and exercise-induced bronchoconstriction in young male conscripts: association only in atopics. Allergy 2005;60:1493-1498.

25 Grzelewski T, Grzelewska A, Majak P, Stelmach W, Kowalska A, Stelmach R, Janas A, Stelmach I: Fractional exhaled nitric oxide (FeNO) may predict exercise-induced bronchoconstriction (EIB) in schoolchildren with atopic asthma. Nitric Oxide 2012;27:82-87.

26 Cowan DC, Hewitt RS, Cowan JO, Palmay R, Williamson A, Lucas SJ, Murrell CJ, Thomas KN, Taylor DR: Exercise-induced wheeze: fraction of exhaled nitric oxide-directed management. Respirology 2010;15:683-690.

27 van den Berge M, Kerstjens HA, Meijer RJ, de Reus DM, Koeter GH, Kauffman HF, Postma DS: Corticosteroid-induced improvement in the $\mathrm{PC}_{20}$ of adenosine monophosphate is more closely associated with reduction in airway inflammation than improvement in the $\mathrm{PC}_{20}$ methacholine. Am J Respir Crit Care Med 2001;164:1127-1132. 